\section{A. ARS BILDUMA \\ ISSN 1989-9262 \\ UPV/EHU Press}

ARSBILDUMA (CC BY-NC-ND 4.0)

https://doi.org/10.1387/ars-bilduma.20438 BIBLID [(2019), 9; 77-93]

Recibido: 05/12/2018 Aceptado: 06/03/2019

\section{SILVIA CAZALLA CANTO}

Universidad de Navarra

Departamento de Historia, Arte y Geografía Edificio Ismael Sánchez Bella

Campus Universitario, $\mathrm{s} / \mathrm{n}$

31080, Pamplona (Navarra)

scazalla@alumni.unav.es

\section{ORCID: 0000-0002-0354-7883}

Grupo de investigación TriviUN (Universidad de Navarra). Proyecto «Teatro, Fiesta y Cultura Visual en la Monarquía Hispánica (ss. XVI-XVIII) Fase II», del Ministerio de Economía y Competitividad (MINECO), Subdirección General de Proyectos de Investigación (FFI2017-86801-P).

Financiación del Scaliger Instituut de la Universidad de Leiden (Países Bajos).

\title{
DE VERSMAADING DER WERELTSCHE YDELHEDEN: EMBLEMATIZANDO LA VANIDAD DEL MUNDO DE ESTELLA. UNA EDICIÓN ILUSTRADA NEERLANDESA
}

\author{
DE VERSMAADING DER WERELTSCHE YDELHEDEN: EMBLEMATIZING THE \\ VANITY OF THE WORLD BY ESTELLA. AN ILLUSTRATED DUTCH EDITION \\ DE VERSMAADING DER WERELTSCHE YDELHEDEN: HET EMBLEMATISEREN
VAN ESTELLA'S LA VANIDAD DEL MUNDO. EEN UNIEKE NEDERLANDSE EDITIE
}

\section{RESUMEN}

En 1712 el neerlandés Everardus van der Hooght publicó una edición única de lujo de La Vanidad del mundo (Salamanca, 1574) de fray Diego de Estella ilustrada con láminas a modo de emblemas. Este trabajo analiza la primera parte del tratado para conocer cuáles fueron los argumentos a los que el predicador protestante otorgó mayor relevancia, que nos ayudarán a comprender los motivos que le llevaron a emblematizar el libro de oro del predicador de Felipe II.

\section{PALABRAS CLAVE}

Fray Diego de Estella; Everardus van der Hooght; Frans van Hoogstraten; Edad Moderna; emblemática; vanitas; España; Países Bajos.

\section{ABSTRAC'}

In 1712 the Dutchman Everardus van der Hooght published a unique edition of The Vanity of the World (Salamanca, 1574) by Fray Diego de Estella illustrated with emblems. This work analyses the first part of the treaty in order to find out what arguments were given greater relevance by the protestant preacher; which will in turn help us grasp the reasons that led him to emblemise the golden book of Philip II's preacher.

\section{KEYWORDS}

Fray Diego de Estella; Everardus van der Hooght; Frans van Hoogstraten; Modern age; emblematic; vanitas; Spain; Netherlands.
ABSTRACT

In 1712 publiceerde de Nederlandse predikant Everardus van der Hooght een unieke, met emblemen geillustreerde editie van De versmaading der wereltsche $y$ delheden (Salamanca, 1574) van frater Diego de Estella. Deze studie analyseert het eerste deel van het tractaat om te ontdekken welke argumenten de protestantse predikant het relevantst achtte; dat helpt ons om te begrijpen waarom hij dit bekende werk van de hofprediker van Filips II emblematiseerde.

\section{STEEKWOORDEN}

Frater Diego de Estella; Everardus van der Hooght; Frans van Hoogstraten; vroegmoderne tijd; emblemen; ijdelheid; Spanje; Nederland. 


\section{INTRODUCCIÓN}

En 1562 vio la luz en Toledo La Vanidad del mundo del franciscano navarro fray Diego de Estella, obra con la que alcanzó la cumbre de su carrera como predicador. Compuesta por tres partes de cien capítulos cada una en su versión definitiva (Salamanca, 1574), recoge y transmite el concepto de vanitas y, en su papel transmisor de ideas y valores morales, trata de condensar las claves necesarias para apartarnos del mal: "despreciando estas vanidades, hemos de servir a Cristo"1. El predicador avanzó por la senda de la literatura ascéticomística que se engendró en el siglo XVI con su tratado, cuyo público traspasó las fronteras hispanas e incluso europeas al ser traducida a distintos idiomas: latín, italiano, francés, inglés, alemán, checo, polaco, flamenco, croata e incluso al árabe. Y a los anteriores se suma el neerlandés.

\section{LA VANIDAD EN PAÍSES BAJOS: DE HOOGSTRATEN A HOOGHT}

Las traducciones neerlandesas de La Vanidad dejan constancia de las redes culturales tendidas entre Países Bajos y España durante el siglo XVII, momento en el que el franciscano despertó el interés del librero y humanista Frans van Hoogstraten (1632-1696), que se convirtió en el principal traductor de la obra española al neerlandés ${ }^{2}$. Todas ellas ofrecen la peculiaridad de tratarse de versiones parciales y en ningún caso completas del original; es decir, el neerlandés no traduce íntegramente el repertorio del franciscano, sino que presenta una selección del que él mismo considera "el libro de oro del sabio sentencioso"3.

Si acudimos a los índices de cada edición, comprobamos como en su primera traducción confecciona una obra compuesta por cincuenta capítulos que posee su correspondencia con los cien capítulos de la primera parte del original (Hoogstraten, 1659). En sus dos ediciones posteriores incrementa los capítulos hasta sesenta y mantiene igualmente la correlación con la española (Hoogstraten, 1662 y 1665). Y en las últimas utiliza la misma estrategia, es

${ }^{*}$ Agradezco a Alejandra Szir las traducciones de las partes oportunas del tratado.

1 ESTELLA, D.: Libro de la Vanidad del mundo (ed. P. Sagüés Azcona). Madrid, Aranzazu, 1980, p. 16.

2 CAZALIACANTO S. "Ia mística hispana convertida en embética neerlandese de fray Diego pe Es. a François van Hoogstraten", en $11^{\circ}$ Congrès International de la Society for Emblem Studies, 2017. (En prensa). 3 SAGÜÉS, P.: "Fray Diego de Estella. Sobre algunas traducciones de sus obras", Revista Española de Teología, vol. XXXVII, 1977, p. 66 decir, codifica aquellas partes que considera más relevantes para presentar una selección de ciento ochenta capítulos divididos en tres libros de sesenta que concuerdan con cada parte de La Vanidad (Hoogstraten, 1663-1665, 1665 y 1692).

Si utilizamos las tablas de contenidos que realizó Sagüés ${ }^{4}$, observaremos como entendió que los cincuenta capítulos de la edición de 1659 y los sesenta de las demás surgidas a partir de 1662 habían sido "seleccionados por el traductor" 5 dejando atrás aquellos no introducidos en la versión neerlandesa. No obstante, la astucia de Hoogstraten es sorprendente y tras una revisión de las ediciones neerlandesas y de las españolas, podemos concluir que en todos los casos mantiene los contenidos de la obra, pues ha sintetizado algunos argumentos que se extendían por varios capítulos en la fuente original ${ }^{6}$.

De esta manera, se conservan traducciones únicas y especiales de La Vanidad, ya que su autor no se ha dedicado meramente a transcribirla, sino que se ha interesado por sus temas y ha realizado una reflexión en torno a ellos hasta que los ha transformado en una edición elaborada que presenta sus argumentos de manera mucho más compendiada. Definitivamente, con esta obra quería llegar al máximo número de lectores, pues su contenido era crucial en un contexto en el que la paz y la vida eran bienes muy preciados.

Destaca una edición neerlandesa publicada en Ámsterdam en 1712 por el predicador protestante Everardus van der Hooght $(1642-1716)^{7}$ bajo el título De versmaading der wereltsche ydelheden (La Vanidad del mundo) (Fig. 1); una obra con la que otorga continuidad al proyecto editorial iniciado por Hoogstraten medio siglo antes, ya que la configura con la misma estructura: tres partes de sesenta capítulos cada una. Justifica su edición manifestando que el tema de la vanidad es una cuestión que nunca debe ser desatendida, ya que alrededor de ella gira la salvación del alma humana; para ello es necesario la copia de libros con el objetivo de "fijar más en la memoria la materia tratada [...] y de interiorizar el contenido"s.

Ibid, p. 67 y 71

Ibid.

CAZALLA CANTO, S.: op. cit.

Everardus estudió teología en la Universidad de Utrecht en 1663; posteriormente empezó su carrera como ministro de la Reformada Iglesia Neerlandesa en 1669 dedicando la mayor parte de su tiempo a la enseñanza y escritura utilizando métodos didácticos para facilitar el catequismo. Para saber más sobre esta figura nos remitimos a FUKS-MANSFELD, R.: "Everardus van der Hooght (1642-1716), the Last of the Christian Hebraists in the Dutch Republic", Studia Rosenthaliana, vol. 38/39, 2005-06, pp. 256-261. 8 HOOGHT, E.: De versmading der Wereltsche Ydelheden. Amsterdam, Jacobus Verheyden, 1712, f. 3r. 


\section{E}

\section{VERSMAADING

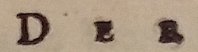

\section{WERELTSCHE YDELHEDEN. begrepen in drie Deelen; \\ Hipt be werken ban ben Itptmunten: Den Boutgeleerte}

D ID A K Y S T E I A

In't Nederduyts vertaalt deur E.V.H.

$D E D E R$ D \& U $\mathbb{R}$,

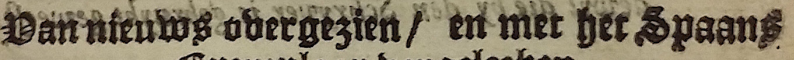
Exemplaar bergeleethen.

En met fchoone Kopere Plaaten rezziert,

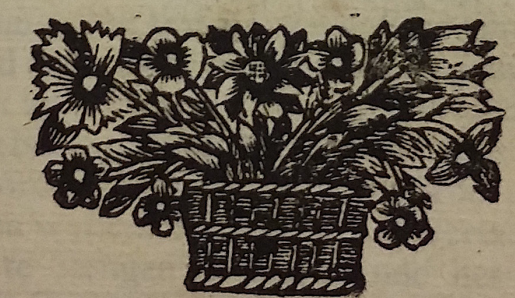

TC AMSTERDAM;

250 J A COB US VEREEYDEN, 200chberthate per op of soingel/ bp or baft-bupg

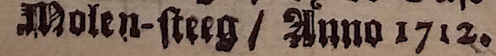

1: Portada de De versmaading der wereltsche ydelheden. Jacobus Verheyden, 1712 Biblioteca de la Universidad de Leiden, 1031 E 52
Si atendemos a la introducción, a la portada y a la estructura, podríamos pensar que es una simple reedición póstuma de las traducciones que Hoogstraten realizó; sin embargo, se halla una novedad que hace de la edición del siglo XVIII, una obra única y especial: la introducción de láminas ilustrativas a modo de emblemas que recorren todo el libro. Sus imágenes y poesías la convierten en una obra dotada de una originalidad inigualable con respecto a las demás traducciones que figuraron en Europa y más allá de sus fronteras. Everardus decide "aportar material para componer didácticos Emblemata", puesto que las imágenes poseen esa capacidad de "instruir ante nuestros ojos". Inserta de esta manera una serie de grabados que, a modo de picturae, muestran una enseñanza con carácter moralizante acompañados de una breve poesía que funciona como epigrama. En definitiva, un conjunto de diecinueve grabados plasma todo un universo que gira en torno a la vanitas, a los pecados del mundo y al ascenso a la gloria divina que, apoyado en los textos poéticos, ahonda en el sentido didáctico de la composición.

La portada ya nos envuelve en el mensaje que se va a transmitir gracias al grabado que aparece, el cual se manifiesta revelador (Fig. 2). Un joven sentado pisa el globo terráqueo rodeado de objetos lujosos como joyas, copas, un abanico con plumas de pavo real (soberbia), un cetro, un escudo e incluso una corona de laureles, mientras señala las tablas de la ley situadas en un altar. A su derecha una mujer con túnica y velo abre la palma de la mano derecha para señalar las tablas mientras sobre su cabeza se atisba una llama de fuego: "tendrá la mano derecha abierta y la izquierda sobre un altar"; "tendrá velada la cabeza [...] tiene esta figura en un lateral un joven con las tablas de Moisés"10, son algunas de las descripciones de la Religión de Ripa. Pero ¿y la llama? "Joven [...] con una llama sobre la cabeza" ${ }^{11}$, describe al hablar de la Piedad. Por otra parte, a la izquierda, una joven figura sostiene una palma en sus manos, símbolo de la victoria: "la palma en la mano, símbolo del premio que tienen en el Cielo aquellos que dominando a las pasiones se han subyugado a sí mismos"12.

Toda la escena queda inundada por los rayos del sol que aparece en el margen superior izquierdo en el que se observan un triángulo, un ojo, los símbolos del alfa y omega y una serpiente que se muerde la cola en su circunferencia, el conocido ouroboros. Los primeros, símbolos de Dios, de su omnipotencia y de su eternidad; el reptil por su parte, manifiesta la desestimación de las grandezas y fortunas de la vida, siendo necesario apreciar tan sólo lo

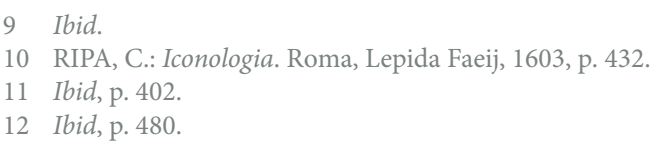




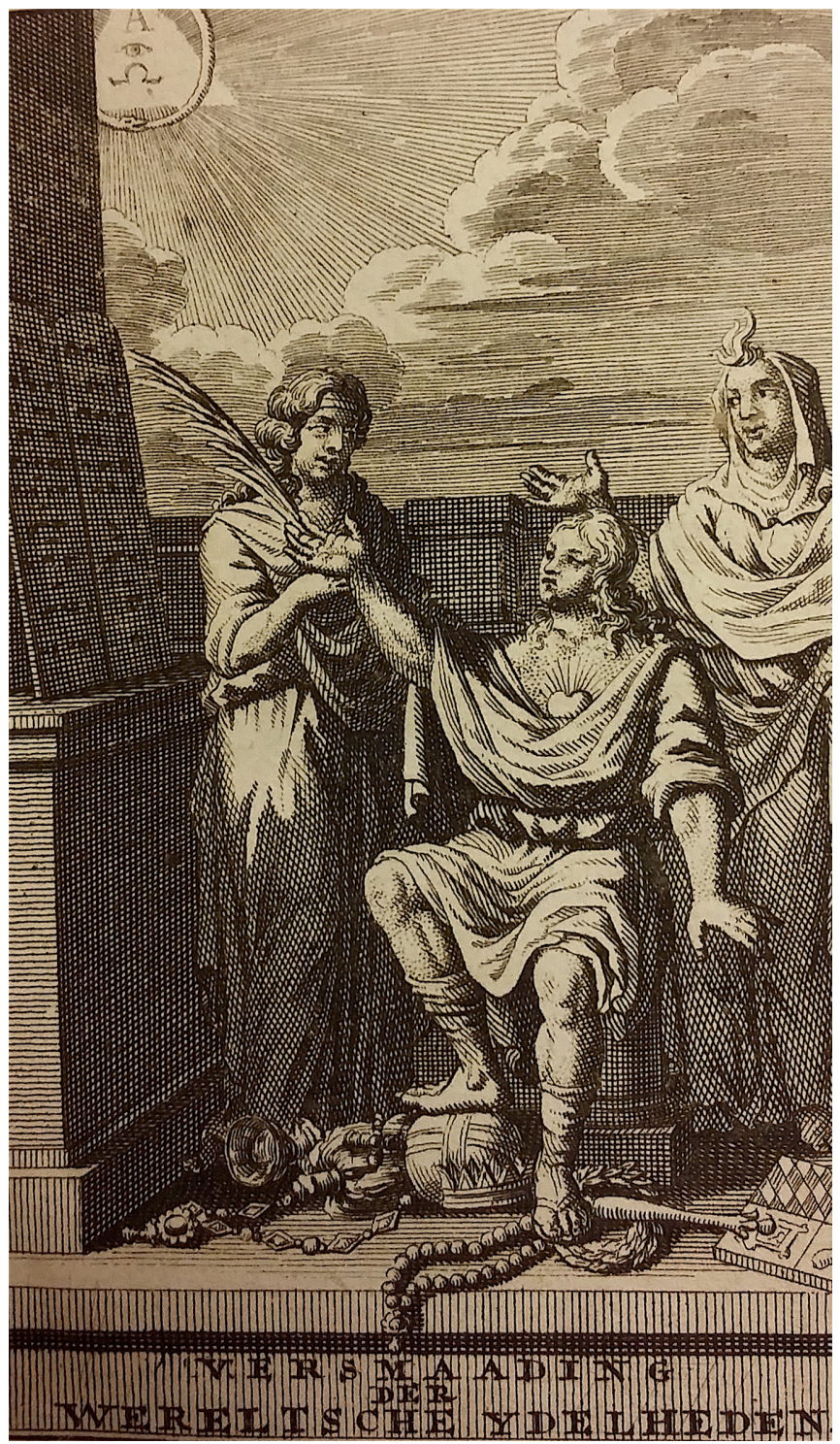

Fig. 2: Grabado de la portada de De versmaading der wereltsche ydelheden. Jacobus Verheyden, 1712. Biblioteca de la Universidad de Leiden, 1031 E 52 eterno, ya que el tiempo todo lo devora, como nos asevera de Juan de Borja ${ }^{13}$. En definitiva, el joven ha tomado conciencia de que los bienes terrenales son perecederos y de que un camino para vencer a la muerte es factible: escapar de sus pasiones, ya que como asevera nuevamente Borja: "estas tornan el alma dura"14. Ante ello deberá encaminarse por la vía contemplativa con la que "el corazón se llega a encender con llamas del amor"15 y habiendo sido atravesado por los rayos del sol "no solamente quedó inflamado y encendido para sí solo, sino que también se halló capaz de transfundirlas y comunicarlas a los otros"16.

La segunda imagen que aparece tras la portada presenta a una joven ataviada a la romana que, coronada con laurel, apoya su brazo derecho, con el que se sostiene la cabeza para presentar una actitud reflexiva -gesto que nos recuerda a la melancolía ${ }^{17}$-, sobre una calavera situada en una mesa (Fig. 3). Mientras, con el izquierdo agarra un gran libro que ha dejado caer al suelo (la Biblia) y que sin duda es la causa de su absorta actitud. La inscripción latina en la base nos indica el asunto que le abstrae: vanitas vanitatum et omnia vanitas (Vanidad de vanidades, todo es vanidad) (Qo 1,2). En definitiva, ambas imágenes son admonitorias de los argumentos que gobiernan las tres partes del libro; se presentan claras y concisas para captar la atención del lector e ir inyectando en su ideario el concepto de la fugacidad de la vida, el rechazo de lo terrenal y la necesidad de una vida contemplativa para alcanzar la gloria celestial.

Con respecto a los emblemas insertados entre los capítulos del libro, es interesante la configuración iconográfica que reflejan. Cada uno de ellos tiene una estructura tripartita, compuestos por un lema o mote, que coincide con uno o varios capítulos de La Vanidad; pictura que presenta una diversidad temática dependiendo de la parte del tratado representado; y, por último, una poesía que simplifica el argumento ${ }^{18}$.

Sabemos los motivos por los que Hooght ilustra la obra; no obstante, no emblematiza cada capítulo ¿Por qué? ¿Cuáles son las ideas de Estella que ha considerado apropiadas enseñar mediante la imagen y palabra, vista y oído? ¿Se está dirigiendo a alguien en concreto y por

13 BORJA, J.: Empresas Morales. Bruselas, Imprenta de Francisco Foppens, 1680, pp. 58-59.

14 Ibid, pp. 406-407.

15 VILLAVA, F.: Empresas Espirituales y Morales. Baeza, Impresor Fernando Díaz de Montoya, 1613, f. 109r 16 GAMBART, A.: Vida simbólica del Glorioso S. Francisco de Sales. Madrid, Imprenta de Antonio Román 1688, p. 123

17 RIPA, C.: op, cit, p. 303

18 El texto poético resulta clave a la hora de descifrar el contenido de la imagen por cuanto es original de Hooght y entra en diálogo directamente con las ideas propuestas con Estella. Dicho diálogo enriquecedor contribuye de manera definitiva a la imagen a la que acompaña, como comprobaremos en el análisis de los emblemas. 


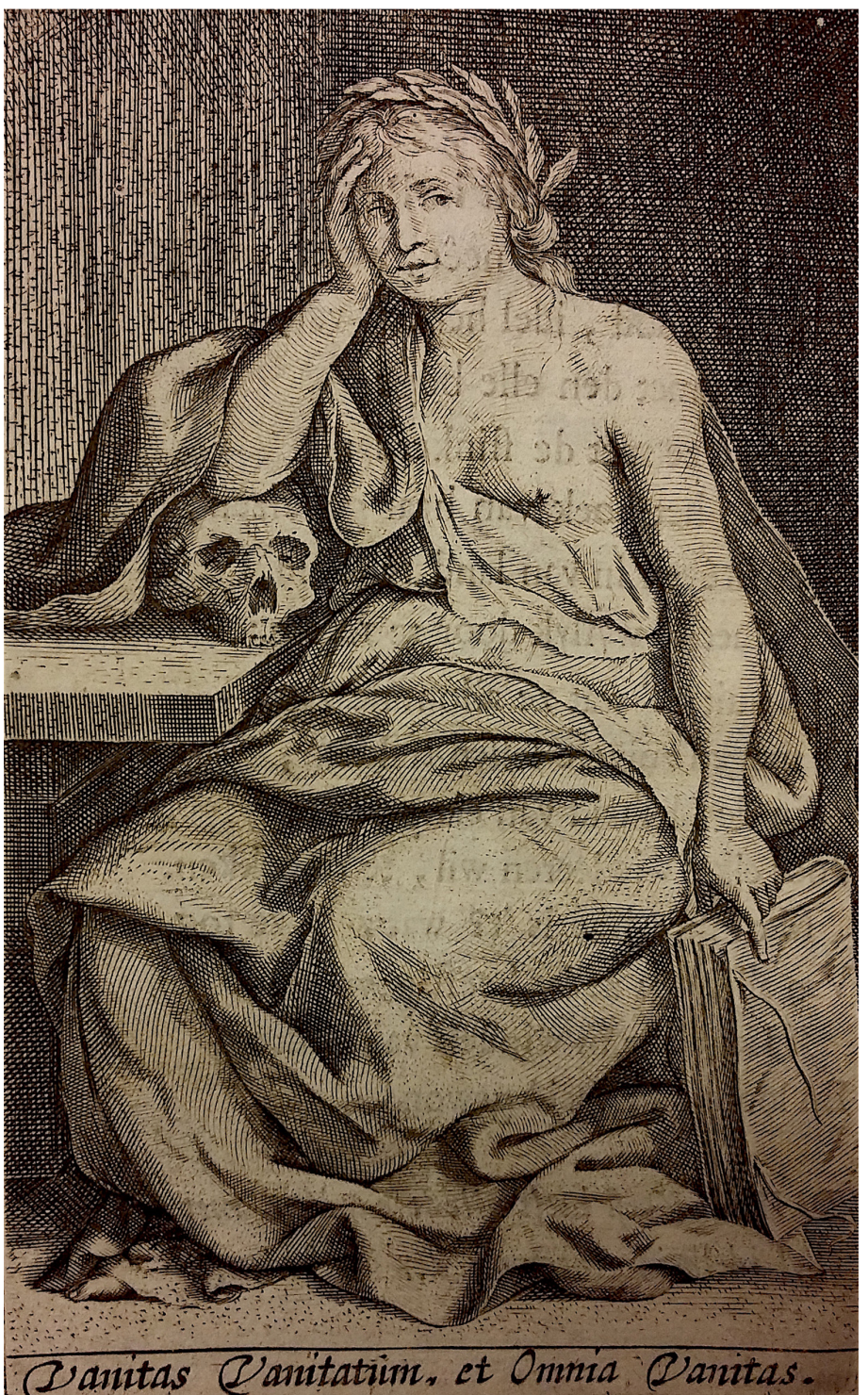

Fig. 3: Grabado que precede al prólogo de De versmaading der wereltsche ydelheden. Jacobus Verheyden, 1712. Biblioteca de la Universidad de Leiden, 1031 E 52 ello se rinde ante argumentos concretos? Es nuestro propósito realizar un análisis de los seis emblemas de la primera parte de La Vanidad neerlandesa para comprender el objetivo que persigue el neerlandés al ilustrarla con seis emblemas en sus sesenta capítulos.

\section{NUNQUAM SATIS DICITUR, QUOD NUNQUAM SATIS DICITUR: DEL PECADO TUVIERON ORIGEN LOS SEÑORÍOS Y MANDOS Y TIRANÍAS DEL MUNDO}

La fugacidad de la vida, la amenaza constante de la muerte y la intrascendencia de lo material abarca todo el contenido de la primera parte de La Vanidad de fray Diego de Estella con la finalidad de desengañar al lector de lo efímero del mundo terrenal para que se concentre en Dios. La vanitas impregna a todas las personas independientemente de su estatus social; no obstante, resulta preciso recordarlo concretamente a los grandes dirigentes, pues cuanto mayor es el alcance del deleite más fácil es saborear los pecados. Un hecho que Everardus conocía perfectamente como demuestran los seis emblemas que ilustran la primera parte del tratado.

En ella existe una clara alusión al poder igualador de la muerte que no relega a ningún individuo; por ello, las escenas quedan protagonizadas por esqueletos y personajes de alta alcurnia como reyes, a los que se suman sabios y militares. La muerte no se presenta sola en las escenas, sino que va acompañada de otras alegorías haciendo una clara alusión al fin terrenal.

Ejemplo de ello se observa desde el capítulo trece, donde introduce dos folios sin enumerar ${ }^{19}$ -como hará con el resto de imágenes y poesías- que contienen el emblema I (Fig. 4). En primer lugar, está el mote Van de idelheid van's Waerelds vriendschap (De la vanidad de la amistad del mundo) que coincide con los capítulos quince y dieciséis de Estella, De la vanidad de las amistades humanas y De la verdadera amistad.

Después del lema se sitúa el epigrama, en el que anticipamos el mensaje del emblema: "los celos y el interés pueden interpretar ingeniosamente los roles [...] virtud y amistad sinceras son cosas sólo comunes a los seguidores de Jesús"20. A su vez, Estella advierte: "si todos ahora se ríen y hacen cortesía es porque pretenden tu favor o aprovecharse de alguna cosa de ti $[\ldots]$ con sólo Jesucristo y sus siervos ten amistad"21.

19 Para facilitar la comprensión y la búsqueda de las referencias a Everardus van der Hooght hemos decidido utilizar la enumeración del folio precedente a los emblemas.

20 HOOGHT, E.: op. cit., f. 42

21 ESTELLA, D.: Libro de la Vanidad del mundo. Alcalá de Henares, Imprenta de Luis Gracián, 1597, ff. 19v y 21 


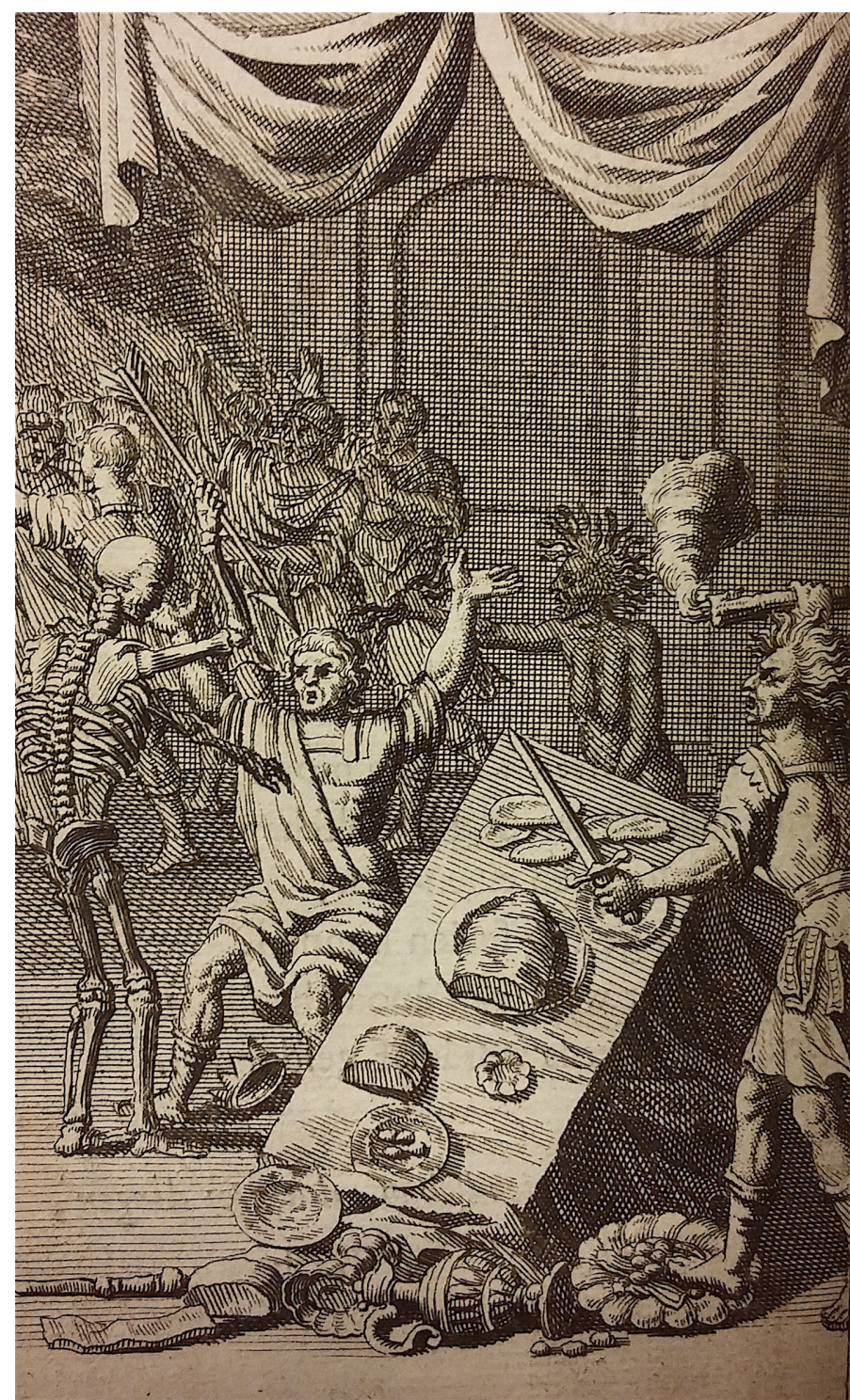

Fig. 4: Emblema I. De la vanidad de la amistad del mundo. Everardus van der Hooght, 1712. Biblioteca de la Universidad de Leiden, 1031 E 52
La pictura nos impresiona con una escena descriptiva y rica icónicamente, pues exhibe un banquete en el que reina el caos a consecuencia de la irrupción de la muerte, representada por un esqueleto; también disfruta la incursión la discordia, con una descripción iconográfica que proviene de Ripa: "una mujer como furia infernal, ataviada con serpientes en el pelo" 22 . No obstante, también puede tratarse de la envidia que se configuró como "una mujer vieja con una cabellera de serpientes"23. Puede resultar oportuno pensar incluso que se trata de la fusión de ambas alegorías, pues como veremos a continuación, es un factor común en el resto de emblemas.

En la escena, mientras el anfitrión, el rey, al que se le acaba de caer la corona, levanta los brazos en gesto inmóvil ante una amenazante flecha que la muerte se dispone a hundir en su pecho, todos huyen para salvar sus vidas sin importarles que el soberano quede acorralado. La idea procede de fray Diego, quien inicia su capítulo quince con la siguiente sentencia: "el amigo de la mesa no permanecerá en el día de la tribulación" ${ }^{24}$. Ante ello pregunta: “ ¿cómo no te libran de la muerte aquellos por cuyo amor mataste tantas veces tu ánima con pecados?" 25 . Y continúa ahondando en esta idea: "la amistad que muestran muchos tener contigo en entrando en el fuego de la tribulación toda se convierte en humo y solo serás dejado en el horno de tus angustias"26; por su parte el neerlandés opina que "las amistades del mundo son como una oscuridad egipcia"27, bebiendo directamente de Is 30,2 "tenéis vuestra confianza en la sombra de Egipto", para significar que así como no hay nada que huya más presto que la sombra, no existe nada más inconstante que la falsa amistad. En definitiva, necio es aquel que piensa que puede confiar en alguien de este mundo, pues "todas cuantas amistades hay debajo del cielo debes tomar como cosas prestadas"28.

El argumento se extiende al siguiente capítulo del navarro, quien enseña: "debes tener amistad con sólo Dios pues todo el tiempo ama" ${ }^{29}$, dando respuesta a la pregunta que nos plantea el neerlandés en su epigrama "la amistad es valorada por la luz solar que da vida [... ¿ ¿se despojaría de esta antorcha el que supiera esto seguro?"30. Precisamente la antorcha juega un papel crucial para identificar a la última de las figuras.

22 RIPA, C.: op. cit., p. 228

23 HERNÁNDEZ MIÑANO, J.D.: Emblemas morales de Sebastián de Covarrubias: iconografía y doctrina de la Contrarreforma. Murcia, Universidad de Murcia, 2015, p. 60.

24 ESTELLA, D.: op. cit., f. 19v

$25 \mathrm{Ibid}$, f. $21 \mathrm{r}$.

26 Ibid, f, 20v

7 HOOGHT, E.: op. cit., f. 42

8 ESTELLA, D.: op. cit., f. $21 \mathrm{r}$

29 Ibid, f. 21 . 
Aparece en el ángulo inferior derecho vestida con una túnica corta y con cabellos parecidos a los de la discordia-envidia. En la mano izquierda porta una espada y en la derecha un hachón del que sale humo y fuego. Todos sus atributos excepto la espada -que podría hacer referencia a su entrada en combate- recuerdan a las Furias Infernales: Tisifone, Alecto y Megera, quienes icónicamente se representan como "mujeres de horrible aspecto [...] con cabellos serpentinos [...] con una tromba de la cual sale flama y humo negro"31. Efectivamente, la representación iconográfica de las Euménides se afianzó como "mujere de cabellera entrelazada con serpientes, túnica corta [...] y en las manos, serpientes, látigo o antorchas encendidas"32. En este caso concreto puede que haga referencia a Alecto encargada de sembrar el odio y la discordia entre los humanos, pues su figura no pas desapercibida por su posible parentesco con la furia de Los horrores de la Guerra de Rubens, donde aparece Alecto, con una antorcha en la mano, simbolizando la autodestrucción y el castigo de todos aquellos que se han excedido en sus derechos ${ }^{33}$.

En definitiva, la única vía de no pagar y ser atormentado por los pecados cometidos en el mundo terrenal ante la inminente llegada de la muerte será la aproximación a Dios, pues "cuando pecas, Él te perdona"34; por ello, confiesan ambos predicadores: "si se quiere observar el camino recto de la amistad" 35 "huye de toda amistad mundana, pues no sirve sino de llevar a los hombres al infierno"36.

El emblema II se sitúa entre las páginas sesenta y seis y sesenta y siete del capítulo diecinueve (Fig. 5). Bajo el mote Van de ydelheid der wereldsche heerschappije (De la vanidad del dominio del mundo) encuentra su equivalente en los capítulos veinticuatro y veintiocho de Estella que versan sobre la vanidad del señorío mundano y de aquellos que desean gobernar el mundo.

30 HOOGHT, E.: op. cit., f. 42 r.

31 RIPA, C.: op, cit, 175

32 ELVIRA BARBA, M.: Arte y mito: manual de iconografía clásica. Madrid, Silex, 2008, p. 152.

33 ROSENTHAL, L. Gender Politics, and allegory in the Art of Rubens. Cambridge, Cambridge University Press, 2005, p. 91

34 ESTELLA, D.: op. cit., f. 22 r.

35 HOOGHT, E.: op. cit., f. 42r

36 ESTELLA, D.: op. cit., f. 22v.

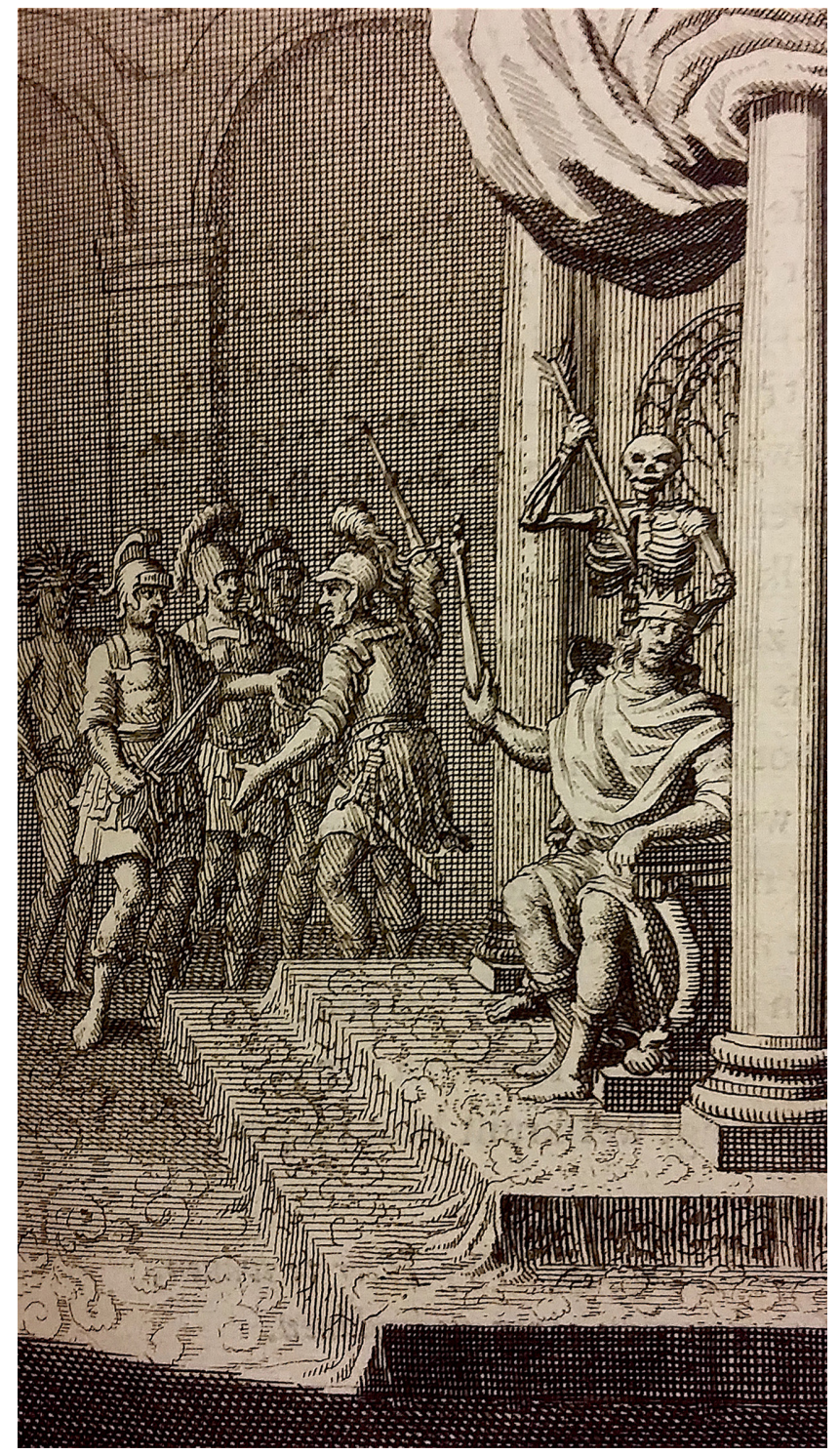

Fig. 5: Emblema II. De la vanidad del dominio del mundo. Everardus van der Hooght, 1712. Biblioteca de la Universidad de Leiden, 1031 E 52 
En la pictura observamos a un rey con un cetro que empuña desde su trono, mientras un grupo de militares se sitúa a su derecha en actitud de disputa. "En el mundo aquellos que desde sus tronos reales agitan los cetros para exhibirse" 37 "suelen ser promovidos a estos estados y señoríos de la tierra indignos"38. La idea de que personas inadecuadas puedan saborear ferozmente el poder que tienen sobre los demás brota de Estella, por ello aconseja: "no quieras señorío de mano del hombre, ni del rey silla de honra", pues bajo su perspectiva "el señorío es propia excelencia de Dios" 39

Dos son las alegorías que aparecen en la imagen: en primer lugar, la muerte que se ubica tras el soberano apuntándole con la flecha; por otro lado, la discordia-envidia acomodada junto a los soldados fomentando la trifulca existente entre ellos.

El franciscano dedica cinco capítulos a este argumento, pues para él resulta crucial el desprecio de todas las grandezas y dominios del mundo. De este modo pregunta a los poderosos: "aunque seas grande prelado, y rey, y emperador ¿Qué hay después? ¿Te librarán estas cosas de la muerte?" 40 ; la propia imagen del neerlandés nos anuncia la respuesta a través del esqueleto que nos mira fijamente antes de que el monarca sucumba a su poder. Por otra parte, el predicador protestante también se cuestiona: “iqué es la autoridad para quienes sólo por obligación ante los tronos se inclinan?" ${ }^{41}$. Pregunta que no es casual, ya que la imposición de todos los súbditos de servir a sus gobernantes es arena movediza en el mundo terrenal, pues como asevera Hooght: "si la plebe colérica desobedeciera ¡cuántos se verían caer abruptamente!" 42 ; y del mismo modo predica el navarro: "las honras traen los peligros y cuando es mayor la honra, tanto es mayor el peligro" ${ }^{\text {. }}$. Por ello, en la imagen la discordia ha sembrado la desobediencia y algunos soldados han desenvainado ya sus armas dispuestos a luchar con aquellos que defenderán al soberano; no obstante, y aunque "ahora parece que el monarca está en lo más hondo del corazón de sus tropas"44 "grande abatimiento y desprecio está guardado para los señores y grandes de este siglo" ${ }^{\text {"45 }}$, ya que "el que tiene señorío en este mundo, tantas cargas trae sobre sí, cuántos son aquellos a

40 Ibid, f. 32

41 HOOGHT, E.: op. cit., f. 66r.

2 Ibid.

3 ESTELLA, D.: op. cit., f. 32r

4 HOOGHT, E.: op. cit., f. 66

45 ESTELLA, D.: op. cit., f. 33r. quien manda"46. Ante ello, concluyen que el desprecio por el dominio y el poder se presenta como única solución pues "es vanidad creerse a sí mismo señor y ser esclavo de sus propios súbditos"47.

\section{NE PERSISTAS IN CORTICE EXTERIOR, NON ATTENDE APPARENTIAM PARA LOS SENTIDOS}

Soberbia, avaricia y lujuria. Si existen tres pecados mortales que hacen que fray Diego de Estella mastique sus palabras para arrojarlas en su escrito son precisamente la soberbia, la avaricia y la lujuria. Para el predicador navarro en estos males nace el desdén divino, pues considera una locura, una perversidad y una abominación detenerse en el engaño de las apariencias exteriores. Ofrece de este modo tres capítulos que critican estas flaquezas de los que Everardus se ocupará para trasformar la verbosidad de Estella en lenguaje figurativo.

El emblema III -presentado entre las páginas ochenta y cuatro y ochenta y cinco del capítulo veinticuatro resulta curioso por cuanto a priori no es identificable con ningún capítulo de La Vanidad (Fig. 6). Como hemos visto, hasta ahora los lemas de Hooght eran iguales a los títulos de Estella; sin embargo, la clave de la tercera imagen neerlandesa se sitúa en la poesía. Lleva por mote Van de idelheid van's Waerelds pragt (De la vanidad del esplendor del mundo) y alude al capítulo treinta y cinco de Estella, De la vanidad de los soberbios edificios. Y será precisamente la frase introductoria de este capítulo el origen de la pictura: “iay de aquel que dice: edificaré para mí grande casa y aposentos espaciosos!”48.

En el grabado observamos a un arquitecto que le muestra a un joven ricamente ataviado y sentado sobre un sillar cuadrado ${ }^{49}$, el plano del edificio que está siendo construido a sus espaldas entre ruinas -donde se atisba además el Tiempo con la guadaña-. Mientras, el esqueleto aparece apuntando con su perniciosa flecha al personaje acaudalado. La idea queda clara en el epigrama: “¿qué grandeza real obtiene un hombre de inmensos edificios

46 Ibid.

47 HOOGHT, E: op cit, f 66 .

48 ESTELLA, D:op cit, f. $48 \mathrm{v}$

49 La tradición simbólica presenta la figura cúbica en ámbitos religiosos para expresar conceptos en relación con la sabiduría y la virtud. GARCÍA MAHÍQUES, R.: "Sedes virtutis quadrata. Consideraciones sobre la iconografía de los santos penitentes", en ZAFRA R. y AZANZA J. J (eds.).: Emblemata aurea. La emblemática en el arte y la literatura del Siglo de Oro. Madrid, Akal, 2000, p. 212 


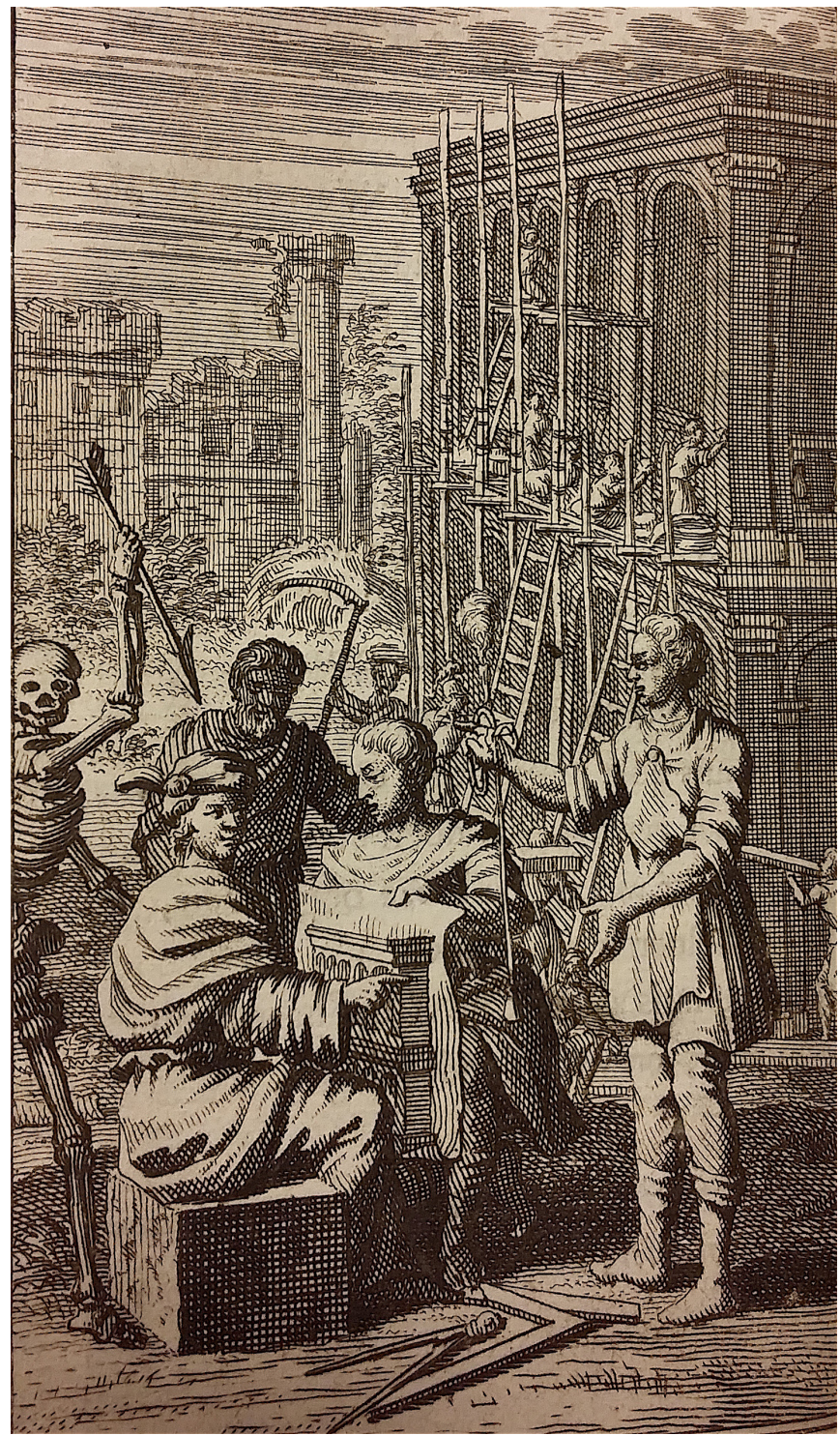

Fig. 6: Emblema III. De la vanidad del esplendor del mundo. Everardus van der Hooght, 1712. Biblioteca de la Universidad de Leiden, 1031 E 52 ostentosos?"50; responde Estella: "vanos son y locos los que se jactan de grandes y suntuosas

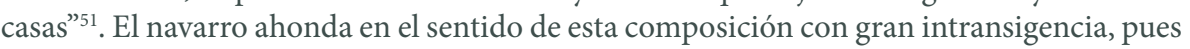
considera ofensiva la construcción de lujosas arquitecturas: "no tuvo el unigénito hijo de Dios donde nacer sino un vil establo [...] y tú, gusano de tierra, que has de morir mañana ¿edificas grandes palacios y altas casas?" 52 ; y del mismo modo advierte el protestante con un símil entre los edificios fastuosos y las lujosas joyas: “iqué comodidad le puede dar a la mujer las piedras preciosas? Seguramente ninguna [...] el oro atrae a los infieles que asedian. Una casa alta será más vulnerable ante los relámpagos y truenos" ${ }^{153}$. No existe, por tanto, bajo el criterio de ambos predicadores ningún tipo de dignidad en esta fábrica: "la casa no contribuye al honor del hombre, el hombre debe primero hacer honrar la casa" estipula el neerlandés"54; "vanidad de vanidades poner tu honra en unas piedras mudas e insensibles" ${ }^{\prime 5}$, concluye el español.

Justo a la derecha del joven un albañil sostiene una plomada, que cuelga sobre una regla, una escuadra o cartabón y un compás, atributos propios de la profesión de arquitecto. ¿Se está debatiendo entre el camino de la virtud y la esclavitud ante sus debilidades? La plomada en literatura emblemática adquiere diversos significados tanto en el plano religioso y político como en el amatorio y "generalmente está relacionada con la idea de prudencia y equilibrio entre dos extremos"56; de ella existen referencias tanto en la hispana como neerlandesa, caso de Sebastián de Covarrubias ${ }^{57}$ y de Otto Vaenius ${ }^{58}$. Por su parte, la regla, la escuadra o cartabón y el compás son símbolos de moderación, como manifiestan los emblemistas Juan de Horozco ${ }^{59}$, Juan de Borja ${ }^{60}$ y Saavedra Fajardo ${ }^{61}$, haciendo extensible así este símbolo a todas las clases sociales.

50 HOOGHT, E.: op. cit., f. 84

52 Ibid.

53 HOOGHT, E: op, cit., f. 84 r.

54 Ibid.

55 ESTELLA, D.: op. cit., f. 49r

56 AZANZA LÓPEZ, J. J.: "Entre el libro de emblemas y el manual de conducta militar: las Empresas Politicas Militares de Pozuelo, obra crepuscular de la emblemática hispana”, Imago. Revista de Emblemática $y$ Cultura Visual, nº 2, 2010, p. 37

57 COVARRUBIAS, S.: Emblemas Morales. Madrid, Imprenta de Luis Sanchez, lib. II, 1610, p. 190.

58 SEBASTIÁN, S.: "Theatro moral de la vida humana, de Otto Vaenius. Lectura y significado de los emblemas", Boletín del Museo e Instituto Camón Aznar, 14, 1983, p. 52; Ibid. "Lectura crítica de la Amorum Emblemata de Otto Vaenius", Boletín del Museo e Instituto Camón Aznar, 21, 1985, p. 27.

59 HOROZCO, J.: Emblemas morales. Segovia, Imprenta de Juan de la Cuesta, 1589, pp. 79-80.

60 BORJA, J.: op. cit., p. 24

61 SAAVEDRA FAJARDO, D.: Idea de un príncipe político crhistiano. Milan, s.n, 1642, pp. 25-31. 
En el emblema de Everardus si trazamos una línea recta desde la mano del albañil hasta la bola de plomo podemos comprobar cómo la plomada está ligeramente ladeada hacia la derecha. ¿Existe la posibilidad de que se centre? Todo depende de la elección por la que opte el mecenas del edificio: "¿quieres tú morar en soberbios palacios de mármol?”" "el esplendor no tiene nada y si es que lo tuviera, sería una carga, tristeza y tortura"63.

La idea de ruinas también aparece en Estella cuando pronuncia: "de aquellos solemnes edificios que por su grande soberbia y vanidad fueron contados entre las siete maravillas del mundo, ya no hay memoria [...] ¿y piensas tú dejar en el mundo perpetua memoria de ti por las casas que labras?" ${ }^{64}$. La presencia del Tiempo blandiendo su guadaña al fondo da voz a la sentencia del franciscano, pues se trata de una admonición sobre lo efímero de la sabiduría, ejemplificada en la arquitectura y en el arquitecto, dando sentido así a la idea de que no sólo son efímeras las vidas humanas, sino todo aquello que mora en la tierra: “Tiempo vendrá y no se tarda, cuando los palacios de los reyes, las altas torres, fuertes castillos y todos cuantos edificios hay sobre la tierra, caerán y no quedará de ellos piedra sobre piedra" ${ }^{65}$. Ante ello, sólo una pregunta resulta factible: "iquién ha puesto sus ojos alguna vez en el esplendor mundano, en tapizados, casas y decoración de interiores, y no lo ha despreciado por vano?"66

"La hermosura vana es, corruptible, momentánea, loca y transitoria, que el tiempo la deshace y viene a parar en muy grande miseria" ${ }^{37}$. Esta sentencia del capítulo treinta y ocho de La Vanidad titulado De la vanidad de la hermosura corporal, constituye, junto con el treinta y nueve, De la verdadera hermosura, el germen del emblema IV de Everardus, que, situado en el capítulo veintisiete, se intercala entre las páginas noventa y seis y noventa y siete (Fig. 7). El lema es igual que el título español: Van de idelheid der ligchámelyke schoonheid (De la vanidad de la belleza corporal)

La pictura queda protagonizada por una joven semidesnuda que, sentada en un trono con un ramillete de flores, agarra una soga con la que encadena por el cuello a tres reyes, quienes se postran ante su hermosura sobre flores marchitas. A sus espaldas se localizan, por un lado, la muerte que la señala con su letal flecha; y por otro, un suntuoso mausoleo que pasa desapercibido para los cuatro protagonistas.

\footnotetext{
62 ESTELLA, D.: op. cit., f. 48r.

(6)

64 ESTELLA, D.: op. cit., f. 49r.

65 Ibid.

6 HOOGHT, E.: op. cit., f. $84 \mathrm{r}$

67 ESTELLA, D.: op. cit., ff. 53r-54
}

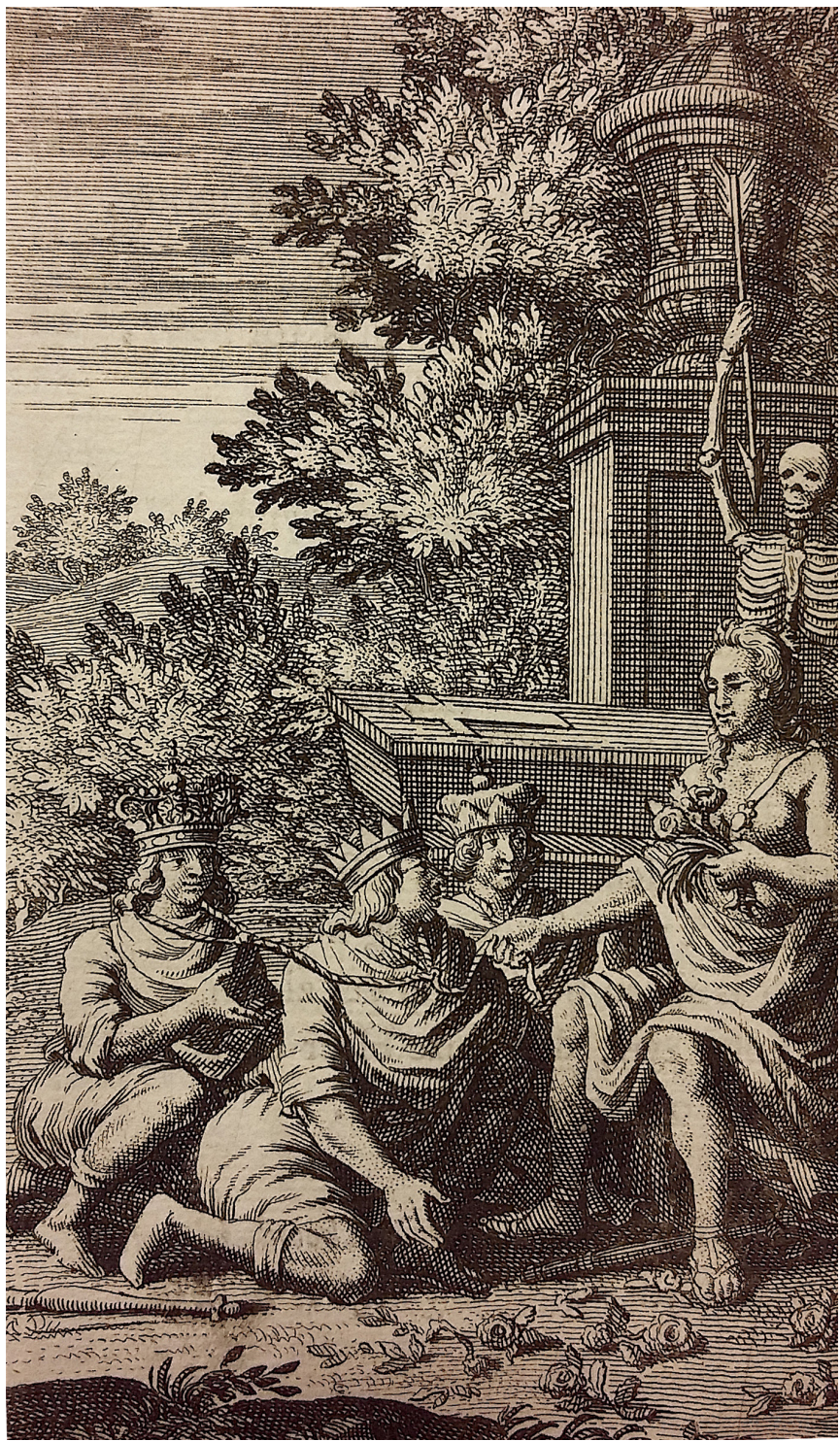

Fig. 7: Emblema IV. De la vanidad de la belleza corporal. Everardus van der Hooght, 1712. Biblioteca de la Universidad de Leiden, 1031 E 52 
La idea de belleza para Ripa adquiere la misma connotación que en ambos predicadores. En su Iconología existe una reflexión que se atisba tanto en Estella como en Hooght "nosotros viendo la belleza de las cosas mortales, no podremos alzarnos y ver aquell pura"68; "la hermosura del cuerpo breve es [...] la del alma dura para siempre" 69 ; "lo hermoso fue atrapado por su belleza y esta no es la apostura verdadera"70. El planteamiento es evidente: el embelesamiento a través de la hermosura terrenal es un engaño ante los ojos, ya que sólo es una fachada, una envoltura de aquella visible no a través de la vista, sino del entendimiento, pues la primera igual que "una flor en el campo es cortada con la guadaña velozmente"71; "así pasa la frescura de la hermosura, como la flor del campo, viniendo la vejez sin ser sentida"72.

La reflexión en torno a las flores que se marchitan y su parangón con la belleza corporal fue un recurso muy utilizado por artistas flamencos y españoles; la brevedad de la vida expresada a través de las flores mustias hace hincapié en la disyuntiva entre aferrarse a los bienes terrenales -fugaces- o ganar el cielo por medio de la virtud ${ }^{73}$. Por ello, ha dispuesto flores ajadas a los pies de la bella joven: "un sabio no tomará ninguna belleza por belleza a la que siempre le espera marchitarse más"74; "entre todas las vanidades que tú debes despreciar como fiel siervo de Jesucristo, una de las muy grandes es la corporal hermosura", dictamina Estella ${ }^{75}$, pues "toda la carne es heno. Secose el heno y cayó la flor", concluye con esta sentencia bíblica (Is 40,6-7) 76 $^{7}$.

Culminan ambos autores con el rechazo por lo bello insistiendo en que sólo es posible el amor por la hermosura del alma. El predicador católico dedica su capítulo treinta y nueve a defender que la verdadera belleza se sitúa en el interior y no en el físico, pues la primera es eterna y la segunda perecedera: "aquella es verdadera hermosura (la del alma), que ni las enfermedades ni la muerte pueden quitar"77; y del mismo modo, le sigue el

68 RIPA, C.: op. cit., p. 42.

69 ESTELLA, D.: op. cit., f. 54r.

70 HOOGHT, E.: op. cit., f. 96r.

1 Ibid.

72 ESTELLA, D.: op. cit., f. 53v.

73 SÁNCHEZ LUQUE, M.: "La vanitas en los cinco sentidos de Brueghel: olfato y tacto", Revista de Filología Románica, V, 2007, p. 297

74 HOOGHT, E.: op. cit., f. 96 r.

75 ESTELLA, D.: op. cit., f. $52 \mathrm{v}$.

6 Ibid, f. 53v.

$77 \mathrm{Ibid}, \mathrm{f} .54 \mathrm{r}$ neerlandés: “iay! cuán rápido y con qué facilidad puede desaparecer"78. En definitiva, todo poder sucumbe ante la belleza terrenal, de ahí que el amor por la belleza del alma sea el único deleite del que se debe disfrutar pues "solo la hermosura de las almas que son fieles es la que atenderá nuestro Señor"79; "ama la verdadera hermosura del alma y alcanzarás la hermosura perpetua para el cuerpo y para el alma en el cielo"80.

\section{SI APPETIS HONOREM PERPETUUM, FUGE TEMPORALEM: ¿QUÉ OTRA COSA PODRÍA SER TAN VANA?}

El apetito por la fortuna, el prestigio, la reputación y el éxito aflora cuando la soberbia y la avaricia subyugan al raciocinio y ponen en peligro la estima divina. Consecuencia inmediata es la perdida de la virtud y humildad que brillan por su ausencia en la toma de decisiones y en los actos acometidos por aquellos que piensan que son honrados cuando en realidad lo único que poseen es ambición. Para no ser abatidos por estos implacables pecados Estella dedica cinco capítulos y Hooght dos emblemas, en los que alumbran el camino a los poderosos para que no naveguen en las turbias y amargas aguas del engaño.

Llegamos al quinto de los emblemas con el que nuevamente Hoohgt no ha ocultado que sigue fielmente varios capítulos de Estella, concretamente del setenta al setenta y tres, que tratan la honra mundana (Fig. 8). Su imagen y epigrama los ha intercalado entre las páginas ciento setenta y ciento setenta y uno del capítulo cuarenta y cinco, bajo el lema Van de idelheid van't Waerelds eere (De la vanidad de la honra mundana).

En la pictura un general romano alza su espada -quizás a modo de sentencia, quizás en agradecimiento y honor- ante tres prisioneros que se encuentran maniatados en el suelo y tres soldados que le rinden pleitesía ante un escenario bélico proporcionado por el ejército en formación del fondo y los cañones, balas y gallardetes que quedan junto a los personajes del primer plano. Tras él tres figuras nos dan las claves de la escena: en primer lugar, la muerte que como hasta ahora, aparece representada por un esqueleto que apunta al genera con una flecha; a su izquierda la discordia-envidia; y, por último, la fama. Finalmente, tanto el texto del estellés como la declaratio del neerlandés nos aportarán la información complementaria a la escena que se está presenciando.

78 HOOGHT, E.: op. cit., f. 96r.

9 Ibid.

80 ESTELLA, D.: op. cit., f. 55v 


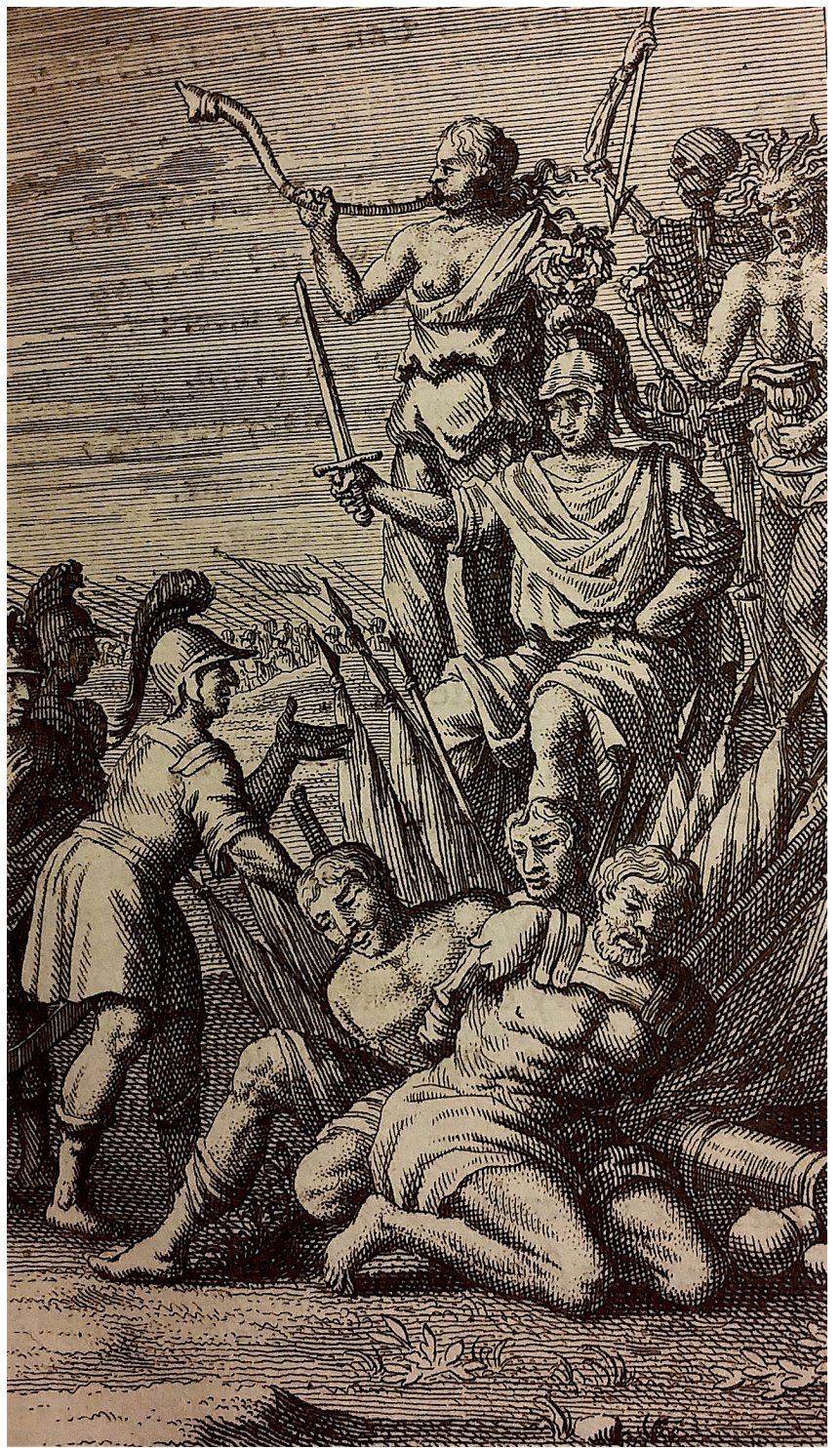

Fig. 8: Emblema V. De la vanidad de la honra mundana. Everardus van der Hooght, 1712. Biblioteca de la Universidad de Leiden, 1031 E 52
"Grandes prelados, príncipes y reyes conocimos que, asentados en altos tronos, les hincaban los hombres las rodillas" ${ }^{\prime 1}$. Fray Diego entiende por honra mundana cualquier fama, reconocimiento, poder o supremacía que una persona pueda tener durante su vida honra sin sentido al ser terrena y, por ende, temporal: "vanas son las honras de este mundo vanos los favores de los grandes y todo pasa muy aprisa" ${ }^{82}$. También se ajusta a esta idea Everardus: "así pasa la vida para los que se entregan al mundo ¡sin ni siquiera pensar por qué se vive!" $"$.

El mensaje se concentra en la evasión de la adquisición del poder en la tierra y en el desprecio por ella: "no busques riquezas pintadas ni falsas honras, sino aquellas que ni el tiempo deshace, ni la vejez destruye, ni por ningún caso se pierden" ${ }^{84}$, pues "si se observa la honra mundana ¿qué otra cosa podría ser tan vana?" los hombres y por ello, conviene que cualquiera que la posea huya de ella, como aconseja el $\operatorname{Ecl}(7,4)$ : "no quieras del hombre señorío, ni del rey silla de honra"86, pues todo es ficción: "una simulación teatral en el convidar y otorgar favores"

A ello se suma una segunda idea: toda la honra mundana es vanidad, efímera, mudable: “¿cuántos reyes hemos visto acompañados de gentes y de caballeros y guardas de los cuales ya no hay memoria? Vino la muerte y convertidos en tierra, no vemos sino sus cenizas y gusanos" ${ }^{\text {"8; }}$; empezamos a ver la imagen que Everardus ha configurado para su Vanidad neerlandesa. El militar al mando que eleva su arma está siendo directamente apuntado por la muerte, quien portará consigo toda la potestad que ahora posee en vida: "muchos romanos ganaron nombre y fama por hechos ilustres en armas [...] aunque muchos cristianos más siguen la doctrina de los antiguos Romanos [...] vanidad es buscar honrar y mayor vanidad buscarla por los medios que tú la buscas" 89 . Existe una auténtica crítica en las palabras del estellés hacia aquellos considerados héroes por sus hazañas en guerras; para
1 Ibid, f. 97v
22 Ibid, f. 100r.
3 HOOGHT, E.: op. cit., f. 170
4 ESTELLA, D.: op. cit., f. 100
55 HOOGHT, E. Op.
ESTH, D.: op. cit., f.170r.
87 HOOGHT, E.: op. cit., f. 170r.
88 ESTELLA, D.: op. cit., f. $99 \mathrm{v}$.
89 Ibid, ff. 101r y 101v 
ello, crea un símil contundentemente didáctico entre estos falsos ídolos y Cristo, pues el Redentor "no la alcanzó [la honra] por riquezas, ni matando enemigos, ni por armas, sino huyendo de la honra y con pobreza y humildad y derramando su propia sangre" 90 .

Si analizamos el resto de personajes presentes, quizás la figura más desconcertante sea la discordia-envidia, pues en un principio nos decantamos por este doble significado atendiendo a una doble premisa: su representación -mujer anciana con cabellos serpentinos (envidia) y una copa en la mano (discordia) ${ }^{91}$-; y un fragmento de la declaratio del predicador protestante, donde habla de la envidia aludiendo a aquellas personas que se someten a otras sólo por conseguir provecho: "su corazón es envidioso, repugnante para personas sinceras; a pesar de todo, es la rutina común para los que se entregan al mundo"92. En este caso podría hacer referencia a los soldados que se postran ante el gobernante, pues son comunes también los ejemplos que propone el español: "honra es la virtud del ánimo, la cual no dan los reyes, ni se alcanza con adulaciones ni se compra con dineros"93. Del mismo modo, compara la honra no con una virtud sino con un pecado alegorizado en la serpiente: "de la víbora es buena su ceniza para curar la mordedura de otra víbora. Pues si eres mordido de la honra [...] mira su brevedad y sanarás con esta consideración"94 Así podría parecer que la figura senil de cabellera viperina queda resuelta, sin embargo, un dato añadido hace que en ella converja otro símbolo e incremente tanto su significado como su presencia en la escena: el freno que porta en su mano derecha.

Resulta tremendamente llamativo el hecho de que, en la poesía cervantina, Canto de Calíope, el freno aparezca sujetando a la envidia ${ }^{95}$, cuando aquí es la envidia quien lo sujeta; sin embargo, en la literatura emblemática este objeto se atribuye a la figura de Némesis, diosa de la venganza ${ }^{96}$ ¿Ha personificado envidia y Némesis en una misma figura? Sabemos que la diosa tiene en ocasiones una representación ambigua, pues guarda numerosas analogías con otras alegorías como la Fortuna, cuyo ejemplo más notable es el grabado La gran fortuna o Némesis de Alberto Durero -del que existe un ejemplar en la

90 Ibid, ff. 101r

91 Resulta interesante como en una edición del XVII se le atribuye a la discordia una antorcha, mientras que en una del XVIII, la copa. RIPA, C.: Iconología. T.II. Perugia, Piergiovanni Costantini, 1765, p. 228

92 HOOGHT, E.: op. cit., f. 170r.

93 ESTELLA, D.: op. cit., f. 100

94 Ibid.

95 ARELLANO, I: "Visiones y símbolos emblemáticos en la poesía de Cervantes", Anales Cervantinos, 34 1998, p. 177.

96 ÁLVAREZ RECIO, L.: Rameras de Babilonia. Historia cultural del anticatolicismo en la Inglaterra Tudor. Salamanca, Universidad de Salamanca, 2006, p. 91
Biblioteca Nacional de España (Invent/ 42688)-; también es identificada con la Justicia ${ }^{97}$ Y se confunde también con la Templanza, "virtud opuesta a la soberbia y temeridad, cuya función principal reside en refrenar y moderar los apetitos del ánimo"98; y con la Razón que presenta Ripa ${ }^{99}$, pues estas poseen el freno como atributo para someter a las pasiones perversas, alegorizadas por serpientes. El freno se manifiesta, por tanto, como indicio de discurso y de razón que se enfrenta a los aspectos que incitan a pecar domándolos; razón recogida por Alciato ${ }^{100}$ cuando presenta a militares que optan por la paz y no por la guerr y Saavedra ${ }^{101}$, quien aconseja al rey a utilizar el freno de la razón sin caer en la tiranía para un buen funcionamiento de su Estado ${ }^{102}$

De esta manera podemos aventurar que el freno no es casual sino causal, pues con su presencia está aconsejando al militar a punto de dictar sentencia a vestirse con las virtudes de la templanza y la razón y dejar de lado sus impulsos primarios y el ímpetu de poder tomar una decisión equivocada: "cosa es más virtuosa domar el hombre sus propias pasiones, que lanzar los demonios"103. Es decir, le alecciona a no dejarse llevar por la inconsciencia de su autoridad, pues "aunque seas grande y poderoso, conoce que eres flaco y pecador, dado caso que ahora te veas ensalzado en alto trono de honra"104; honra que le otorgan aquellos que esperan de él una actitud concreta, aunque sólo sea "alabanza, agasajo y nada más [... y en la mayor parte de su discurso se esconda mucho desprecio"105.

Finalmente, a la derecha del protagonista una mujer con un ramo de flores suena la trompeta; objeto ligado a la buena fama y gloria: "con la trompeta en mano se comunica a pueblo las decisiones del príncipe"106, dictamen que está a punto de tomar con respecto a los tres presos que se disponen a sus pies.

97 GONZÁLEZ DE ZÁRATE, J. M.: "Durero y los Hieroglyphica. Tres estampas y una pintura, Némesis (La Gran Fortuna), la Justicia, Melancolía I, Cristo ante los doctores”, Archivo Español de Arte, 79, 313 2006, p. 8.

98 ASENCIO GONZÁLEZ, E.: La mitología clásica en la emblemática española. Córdoba, Universidad de Córdoba, 2004, p. 217.

99 RIPA, C.: Iconologia, 1603 , p. 426.

00 ALCIATO, A.: Emblematum liber. Lion, Guillermo Rovilio, 1549, p. 48

01 SAAVEDRA FAJARDO, D.: op. cit., pp. 134-145.

102 ARELLANO, I.: op. cit., p. 177.

103 ESTELLA, D.: op. cit., f. $97 \mathrm{v}$

104 Ibid.

05 HOOGHT, E.: op. cit., f. 170

106 RIPA, C.: Iconologia, 1603, p. 192 
De nuevo se plantea el mismo dilema: ¿qué hacer si se posee potestad y se desea la gloria y fama que una decisión mundana puede otorgarte? La respuesta nos la da fray Diego: "si andas dentro de la honra de este mundo, necesario es tener mucho seso y ser amigo de Dios"107; una vez más, la Razón debe frenar la vileza. Razón que haciendo buen uso de ella, te llevará a estimar la honra divina: "huye de estas honras mundanas y serás honrado en el Cielo"108, pues “¿qué cosa es peor que la vanidad que además es tan común entre pobres y ricos?"109.

Concluimos nuestro recorrido con el emblema VI que engloba el capítulo cuarenta y ocho de La Vanidad neerlandesa (Fig. 9). Su mote Van de idelheid der Waereldsche voorspoed (De la vanidad de la prosperidad mundana) se presenta junto al epigrama tras la pictura y en paralelismo con el capítulo setenta y seis del navarro, De la vanidad de la prosperidad mundana, que bien podría ser una continuidad del emblema y capítulos anteriores, puesto que nuevamente tanto Everardus como fray Diego entienden por prosperidad, lo mismo que por honra: potestad, autoridad o gloria que pueda desear, tener y ejercer una persona en el mundo.

La imagen es la más rica icónicamente puesto que son seis las alegorías que se disponen alrededor de la figura del rey. Inicia Estella con una sentencia que anticipa la idea que va desarrollar: "la prosperidad de los locos los ha de destruir" ${ }^{10} ;$ y del mismo modo declara el neerlandés: "nunca llamaron sabio a quien en la prosperidad terrena estableció su tranquilidad y esperanza"111. El concepto que quieren transmitir es claro: no abandonarse a la felicidad, poder, fortuna ni gloria porque todo ello conlleva un gran peligro; de hecho, la amenaza de descuidar las virtudes y quehaceres cristianos es constante: "mucho debes temer en la prosperidad del mundo si quieres conservar la humildad del corazón y servir a Jesucristo"112. Consecuencia inmediata es que en ese estado de bienestar la falsedad juegue un papel protagonista: "cuando uno estando en prosperidad es amado, incierto es si es amada la persona o la prosperidad y [...] en las honras y prosperidades pierden la vida las virtudes", asevera Estella ${ }^{113}$.

107 ESTELLA, D.: op. cit., f. 98r $108 \mathrm{Ibid}$, f. 99v

109 HOOGHT, E: op cit, f. 170 .

110 ESTTELA, D.

111 HOOGHT, E: op. cit, f. 108 .

12 ESTELIA, D. op. cit. 105

113 Ibid.

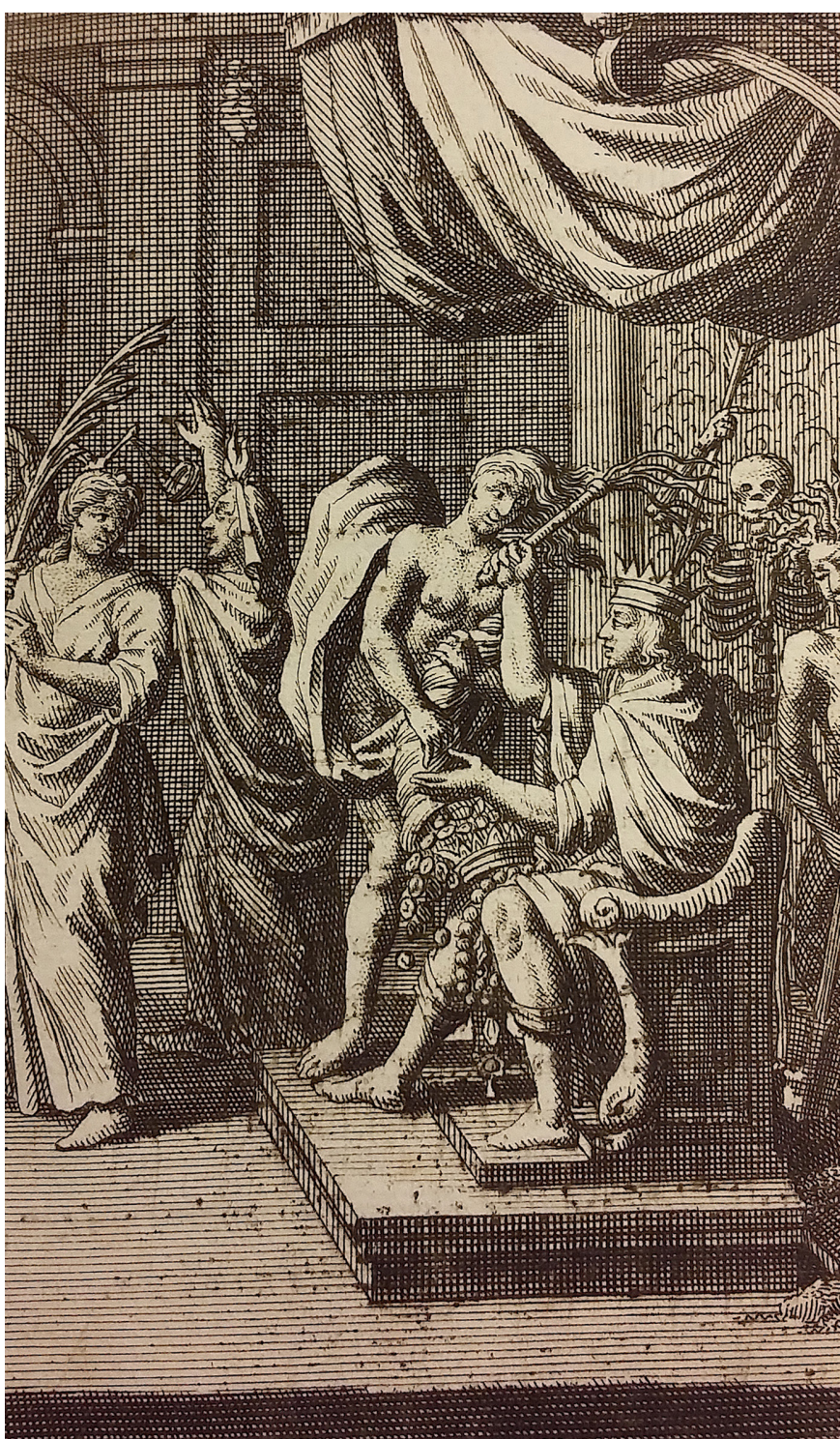

Fig. 9: Emblema VI. De la vanidad de la prosperidad mundana. Everardus van der Hooght, 1712. Biblioteca de la Universidad de Leiden, 1031 E 52 
La referencia a la muerte de las virtudes resulta clave a la hora de entender la pictura. En ella, un rey levanta su flagelo con actitud amenazadora sobre un trono sustentado po un delfín; mamífero que recuerda al monarca la obligación de procurar seguridad a sus súbditos ${ }^{114}$. Frente a él, tres mujeres: una que le mira directamente, otra que le da la espalda y la última casi inapreciable.

La del fondo lleva una balanza con platillos desestabilizados. Es conocido que la balanza es el símbolo de la Justicia ${ }^{115}$. Por otro lado, la mujer que se gira hacia el monarca sostiene una palma de la victoria ${ }^{116}$; si pensamos en la virtud (Justicia) que personaliza su compañera en el desprecio por la prosperidad, como nos aconsejan los predicadores, es inevitable no recordar la empresa CVIII de Juan de Borja, Meliore Sequenti (Al que sigue lo mejor), en el que dispone una hoja de palma para significar que "la auténtica honra es la que consiste en seguir la virtud"117. También Covarrubias utiliza dos palmas en el emblema XLI de su tercera centuria, Negata macrum donata reducti opimun (La palma si se niega, consume, si se otorga, ilustra), y simboliza que al final de la vida dependiendo del comportamiento que se haya tenido se recibirá una u otra: virtud o pecados es la coyuntura planteada por el toledano. Por lo tanto, conseguir alcanzar la virtud (balanza) será premiado con la victoria, cuyo símbolo es la palma. Como señala Estella: "gran virtud es luchar con la prosperidad y no ser de ella vencido"118. ¿Está planteando el mismo debate Everardus? Para responder a esta pregunta es necesario conocer la identidad del personaje que aparece junto al soberano.

No obstante, justo al lado de la Justicia se encuentra la Religión y la Piedad ${ }^{119}$. Religión y Piedad son dos conceptos que van de la mano, ya que la Religión tiene su base en la Piedad y la Piedad puede ser concebida como propia de almas religiosas. Esta figura como hemos anticipado le da la espalda al rey con el látigo. Si atiza a la Justicia, no habrá victoria ni quedará en él Piedad ni Religión, garantiza Estella: "anejo es el olvido de Dios a la prosperidad"120. Todo será oscuridad, ya que "en la vanidad se apaga una luz"121 y "así ciega esta mundana y loca prosperidad, que no ve al Bienhechor"122.

114 ALCIATO, A.: op. cit., p. 42.

115 COVARRUBIAS, S.: op. cit., p. 215; GONZÁLEZ DE ZÁRATE, J. M.: Emblemas regio-politicos de Juan de Solórzano. Madrid, Ediciones Tuero, 1987, p. 121; ELVIRA BARBA, M.: op, cit., p. 330

116 RIPA, C.: Iconologia, 1603, p. 480

17 BORJA, J.: op. cit., p. 222

118 ESTELLA, D: op cit, f. 105

119 Recordemos que esta imagen fue descrita cuando examinábamos la portada.

120 ESTELLA, D.: op. cit., f. $105 \mathrm{r}$.

21 HOOGHT, E.: op. cit., f. 180

122 ESTELLA, D.: op. cit., f. 105v
Son tres los sujetos que nos quedan por identificar, dos de ellos, ya conocidos gracias a los emblemas predecesores: la muerte apuntando con su flecha al monarca, que significa una vez más que la inminente llegada del fin es certera y alecciona sobre la necesidad de reflexionar acerca de este mensaje: "no te olvides de tu Dios [...] cuando estuvieres harto y morares en hermosas casas, y fueres rico de oro y plata, ganados y hacienda" (Dt 8,11 $13)^{123}$; y por otro lado, la discordia-envidia que con una pala en mano socava un hoyo alrededor del trono del soberano, puesto que quizás, él mismo yendo en contra de un buen acto cristiano y de lo que le aconsejan ambos predicadores, está cavando su propia tumba.

Por último, junto al rey una figura completa el significado que tanto Everardus como Estella quieren transmitir mediante la vista y el oído: "ella viene y va como la marea [...] y seguro se le escapará al final", asegura el protestante ${ }^{124}$; "así la tomarás como cosa emprestada [...] con saber que muy presto pasará aquel trabajo", afirma Estella ${ }^{125}$. Pero, ¿quién es ella? Cuando nos fijamos en la imagen propuesta por el neerlandés observamos una joven figura que desnuda aparece con un manto en vuelo, todos los mechones de su cabellera en la parte delantera de su cara y con una cornucopia en la mano. Inevitablemente si atendemos sólo a su apariencia encontramos un símil en el emblema XVI de Alciato sobre la Ocasión donde una mujer aparece con el "cabello delante a mi cabeza por si alguno permitiere irme no pueda por detrás después tomarme"126; una representación atribuida al escultor Fidias cuando dibujó a la ocasión como "una mujer con los cabellos sueltos sobre el rostro, de modo que la nuca quedaba toda descubierta y calva"127. La idea de presentarla calva por detrás mientras en su frente convergen todos los mechones denota la única oportunidad para atraparla ${ }^{128}$. Así lo muestra Hooght en su declaratio: "un momento después ella se dará la vuelta hacia un refugio visible, un poco más tarde hacia el incendio de la adversidad"129.

Sin embargo, un segundo asunto se desprende si atendemos a la poesía del neerlandés: “¿le sopla el viento de lleno en la vela? [...] ahora hacia la bahía de refugio visible"130. Viento, vela y bahía son elementos que no pueden pasar desapercibidos, ya que la imagen marítima

123 Ibid.

124 HOOGHT, E.: op. cit., f. 180 r.

25 ESTELLA, D: op cit, f 105

126 ALCIATO, A. op. cit, p. 37.

127 AULLÓN DE HARO, P.: Barroco. Madrid, Verbum, 2013, p. 1131.

128 SEBASTIÁN, S.: Alciato. Emblemas. Madrid, Akal, 1993, pp. 160-161

29 HOOGHT, E.: op. cit., f. 180 r.

$130 \mathrm{Ibid}$. 
y los atributos mencionados por Hooght van de la mano de la Fortuna ${ }^{131}$, aunque la Ocasión también aparece ante un paisaje marino. Tendríamos por lo tanto dos alegorías encarnadas en una sola figura: Ocasión y Fortuna.

Obviamente el protagonista ha atrapado y se ha beneficiado de la oportunidad de ser afortunado; no obstante, existe un dato adicional que hace pensar que Everardus va más allá e incorpora otra alusión en dicha figura: no sostiene una cornucopia colmada de frutos, sino que está derramando todo tipo de objetos valiosos tales como joyas, dinero e incluso una corona. "Engañosas son las prosperidades mundanas, y muy presto se acaban"132; "corta fortuna vana será rara vez otra cosa que un obstáculo en el camino de la salvación"133. Con estas dos sentencias concluyentes llegamos al último rasgo de esta alegoría: la Liberalidad. De "corta fortuna" habla Everardus, de "presto se acaban", Estella; esta brevedad es derramada por la Liberalidad, una mujer con un cuerno en la mano izquierda que "esparce objetos lujosos y dinero [...] muestra que recibir favores y riquezas de manera correcta es parte de la liberalidad"134. Es decir, aquel que posea riquezas debe mostrar gratitud por su suerte, pero sobre todo llevar a cabo dos virtudes primordiales a la hora de encaminarse en la vía de Dios: la caridad y humildad. Como asevera el italiano "es más noble acción y más beata donar a otros sus cosas"135.

En definitiva, la ocasión le otorga al rey la oportunidad de aprovechar la Fortuna presente y de emplearla provechosamente con Justicia y de manera cristiana para salir victorioso ante el apremiante fin, teniendo como bases la caridad y humildad. Todo ello sin olvidar que la "pérdida de bienes es segura"136 por cuanto la honra de este mundo es perecedera y voluble. Ante ello sólo un camino es adecuado: “desprecia de corazón la felicidad del mundo presente y alcanzarás la verdadera honra que para siempre dura"137.

\section{CONCLUSIONES}

Everardus van der Hooght fue capaz de convertir La Vanidad del mundo y en concreto, la traducción que de ella hizo al neerlandés François van Hoogstraten, en un libro de emblemas al utilizar las ideas que fray Diego de Estella expuso y componer picturae y suscriptio que impregnaran cada página con el aroma de la vanitas. De hecho, la muerte es protagonista en todas las escenas, pues el mensaje que desea transmitir el protestante es claro: el triunfo y poder igualador de la muerte. Para ello recurre siempre a la misma representación, donde un rey o un personaje ricamente ataviado están a punto de ser atravesados por la letal flecha que sustenta un esqueleto. Es decir, su primer objetivo es mostrar que la muerte no entiende de estamentos y para ello, son necesarias imágenes que recuerden a los poderosos el fin de sus días.

En efecto, la idea de poder resulta clave para comprender los argumentos a los que el neerlandés ha otorgado especial relevancia dentro de los contenidos de La Vanidad. Todos sus emblemas hacen referencia al deseo de obtener poder (como fingir una amistad por beneficio propio), a la valoración de las apariencias exteriores (como la construcción de soberbios edificios como manifestación de supremacía), y al mal uso de la autoridad (como flagelar metafóricamente toda justicia). En definitiva, la pretensión de honra y prosperidad mundana suprime las virtudes del ser humano; pecado mortal que le aleja del verdadero camino: Dios.

Para ello, ambos predicadores aconsejan cultivar el alma, pues la noción de una vía para vencer a la muerte es factible. ¿Cuáles son los recursos necesarios para poder triunfar sobre ella y acceder a Dios? Serán la segunda y tercera partes del tratado las que aporten las claves necesarias con las que tanto fray Diego de Estella, para su público general, como Everardus van der Hooght, con un colectivo particular al que va destinado (como nos desvelará en su última introducción), aleccionen con la finalidad de alcanzar y disfrutar la gloria divina.

131 COVARRUBIAS, D.: op. cit., pp. 65, 134 y 267.

132 ESTELLA, D.: op. cit., f. 105 r.

133 HOOGHT E. op cit, f 180

134 RIPA, C.: Iconologia, 1603, p. 292.

135 Ibid.

136 HOOGHT, E.: op. cit., f. 180

137 ESTELLA, D.: op. cit., f. 105v 


\section{BIBLIOGRAFÍA}

ALVÁREZ RECIO, L.: Rameras de Babilonia. Historia cultural del anticatolicismo en la Inglaterra Tudor. Salamanca, Universidad de Salamanca, 2006.

ARELLANO, I.: "Visiones y símbolos emblemáticos en la poesía de Cervantes", Anales Cervantinos, 34, 1998, pp. 169-212.

ASENCIO GONZÁLEZ, E.: La mitología clásica en la emblemática española. Córdoba, Universidad de Córdoba, 2004

AULLÓN DE HARO, P.: Barroco. Madrid, Verbum, 2013

AZANZA LÓPEZ, J. J.: "Entre el libro de emblemas y el manual de conducta militar: las Empresas Políticas Militares de Pozuelo, obra crepuscular de la emblemática hispana", Imago. Revista de Emblemática y Cultura Visual, nº 2, 2010, pp. 25-48.

BORJA, J.: Empresas Morales. Bruselas, Imprenta de Francisco Foppens, 1680.

CAZALLA CANTO, S.: "La mística hispana convertida en emblemática neerlandesa: de fray Diego de Estella a François van Hoogstraten”, en $11^{e}$ Congrès International de la Society for Emblem Studies, 2017. (En prensa).

COVARRUBIAS, S.: Emblemas Morales. Madrid, Imprenta de Luis Sanchez, 1610.

ELVIRA BARBA, M.: Arte y mito: manual de iconografía clásica. Madrid, Silex, 2008.

ESTELLA, D.: Libro de la Vanidad del mundo. Alcalá de Henares, Imprenta de Luis Gracián, 1597.

ESTELLA, D.: Libro de la Vanidad del mundo (ed. P. Sagüés Azcona). Madrid, Aranzazu, 1980

FUKS-MANSFELD, R.: "Everardus van der Hooght (1642-1716), the Last of the Christian Hebraists in the Dutch Republic", Studia Rosenthaliana, vol. 38/39, 2005-06, pp. 256-261.

GAMBART, A.: Vida simbólica del Glorioso S. Francisco de Sales. Madrid, Imprenta de Antonio Román, 1688

GARCÍA MAHÍQUES, R.: "Sedes virtutis quadrata. Consideraciones sobre la iconografía de los santos penitentes", en ZAFRA R. y AZANZA J. J (eds.).: Emblemata aurea. La emblemática en el arte y la literatura del Siglo de Oro. Madrid, Akal, 2000, pp. 209-224.
GONZÁLEZ DE ZÁRATE, J. M.: Emblemas regio-politicos de Juan de Solorzano. Madrid, Ediciones Tuero, 1987.

GONZÁLEZ DE ZÁRATE, J. M.: "Durero y los Hieroglyphica. Tres estampas y una pintura, Némesis (La Gran Fortuna), la Justicia, Melancolía I, Cristo ante los doctores”, Archivo Español de Arte, 79, 313, 2006, pp. 7-22.

HERNÁNDEZ MIÑANO, J. D.: Emblemas morales de Sebastián de Covarrubias: iconografía y doctrina de la Contrarreforma. Murcia, Universidad de Murcia, 2015.

HOOGHT, E.: De versmading der Wereltsche Ydelheden. Amsterdam, Jacobus Verheyden, 1712

HOROZCO, J.: Emblemas morales. Segovia, Imprenta de Juan de la Cuesta, 1589.

RIPA, C.: Iconologia. Roma, Lepida Faeij, 1603.

RIPA, C.: Iconologia. T.II. Perugia, Piergiovanni Costantini, 1765.

ROSENTHAL, L.: Gender, Politics, and allegory in the Art of Rubens. Cambridge, Cambridge University Press, 2005.

SAAVEDRA FAJARDO, D.: Idea de un príncipe político Christiano. Milán, s.n, 1642.

SAGÜÉS, P.: "Fray Diego de Estella. Sobre algunas traducciones de sus obras", Revista Española de Teología, vol. XXXVII, 1977, pp. 33-83.

SÁNCHEZ LUQUE, M.: "La vanitas en los cinco sentidos de Brueghel: olfato y tacto", Revista de Filología Románica, V, 2007, pp. 296-304.

SEBASTIÁN, S.: "Theatro moral de la vida humana, de Otto Vaenius. Lectura y significado de los emblemas", Boletín del Museo e Instituto Camón Aznar, 14, 1983, pp. 7-92.

SEBASTIÁN, S.: "Lectura crítica de la Amorum Emblemata de Otto Vaenius", Boletín del Museo e Instituto Camón Aznar, 21, 1985, pp. 5-112.

VILLAVA, F.: Empresas Espirituales y Morales. Baeza, Impresor Fernando Díaz de Montoya, 1613 